\title{
PENGARUH GREEN MARKETING TOOL'S TERHADAP PERILAKU PEMBELIAN KONSUMEN PADA PRODUK LAMPU PHILIPS LED
}

\author{
I Made Satria Putra Wibawa ${ }^{1}$ \\ I Gde Ketut Warmika ${ }^{2}$
}

${ }^{1,2}$ Fakultas Ekonomi dan Bisnis Universitas Udayana (Unud), Bali, Indonesia e-mail: strputrawibawa@gmail.com

\begin{abstract}
ABSTRAK
Tujuan penelitian ini adalah untuk megetahui pengaruh green marketing Tool's terhadap perilaku pembelian konsumen. Penelitian ini dilakukan pada produk lampu Philips LED di Denpasar. Jumlah sampel yang dipilih sebanyak 112 orang, dengan metode purposive sampling. Pengumpulan data dilakukan melalui kuisioner, dengan teknik analisis data yang digunakan adalah regresi liniear berganda. Hasil penelitian ini menunjukan bahwa alat green marketing Tool's yang terdiri dari eco-label, eco-brand, dan environmental advertisement berpengaruh secara positif dan signifikan terhadap perilaku pembelian konsumen. Hal ini menunjukan bahwa konsumen yang menyadari pentingnya produk yang ramah lingkungan dapat mendorong keputusan pembelian suatu produk.
\end{abstract}

Kata kunci: green marketing tool's, eco-label, eco-brand, environmental advertisement, perilaku pembelian konsumen

\begin{abstract}
The purpose of this study was to determine the effect of green marketing Tool's on consumer buying behavior. This research was conducted on Philips LED lighting products in Denpasar. The number of samples chosen was 112 people, with purposive sampling method. Data collection was done through questionnaire, with data analysis technique used is multiple liniear regression. The results of this study show that the tool of green marketing tool that consists of eco-label, eco-brand, and environmental advertisement have a positive and significant effect on consumer purchasing behavior. This shows that consumers who realize the importance of environmentally friendly products can encourage the decision to purchase a product.
\end{abstract}

Keywords: green marketing tool's, eco-label, eco-brand, environmental advertisement, consumer buying behavior 


\section{PENDAHULUAN}

Era pemanasan global yang menimbulkan kekhawatiran tentang lingkungan tidak hanya menjadi isu publik yang signifikan tetapi juga topik penting tentang penelitian akademik. Kesadaran akan lingkungan, telah merubah cara pandang dan pola hidup dari manusia dan para pelaku usaha. Sebuah perubahan positif dalam perilaku konsumen terhadap produk terkait lingkungan dapat dilihat karena tingkat peningkatan kesadaran lingkungan sejak tahun 1970-an. Hal ini ditunjukkan pada perubahan pola pendekatan bisnis yang mulai mengarah pada aktivitas bisnis berbasis kelestarian lingkungan. Pemasaran yang menggunakan kelestarian lingkungan sebagai dasarnya, merupakan cara baru dalam pemasaran dan merupakan suatu peluang yang sangat strategis dan potensial baik pada pelaku bisnis dan masyarakat sebagai konsumen.

Green marketing adalah sebuah istilah yang muncul sekitar akhir tahun 1980, yang merupakan pemasaran yang menggunakan isu tentang lingkungan sebagai strategi untuk memasarkan produk. Ini membuat kepekaan dunia usaha semakin tinggi terhadap lingkungan hidup. Perubahan ini menimbulkan tantangan yang harus dijawab bagi perusahaan, bisa berupa ancaman atau peluang.

Green Marketing Tool's seperti eco-label, eco-brand, dan environmental advertisement akan mempermudah persepsi dan kesadaran akan atribut dan karakteristik produk hijau, sehingga, membimbing mereka membeli produk yang ramah lingkungan. Dengan diterapkannya alat-alat kebijakan ini memberikan peran penting kepada perilaku pembelian konsumen untuk membeli produk yang ramah lingkungan. 
Tujuan green marketing melalui pemenuhan kebutuhan dan keinginan konsumen pada sasaran pasar harus didukung oleh pemahaman perilaku konsumen. Mempelajari faktor-faktor penentu perilaku pembelian hijau konsumen tentu saja akan menguntungkan dan mempermudah pemasar hijau. Kotler (2008:202) menyatakan bahwa berkaitan dengan perilaku konsumen, dalam hal ini penting diperhatikan konsep pemasaran dimana kunci untuk mewujudkan tujuan organisasi terletak pada kemampuan organisasi dalam menciptakan, memberikan, dan mengkomunikasikan nilai pelanggan (customer value) kepada pasar sasarannya secara lebih efektif dibandingkan pada pesaing. Organisasi perlu mendapatkan kepercayaan dari konsumen tidak melalui mengatakan frase catchy (marketing hijau) tapi, sebaliknya mereka harus menerapkannya misalnya, apa pun yang mereka katakan tentang produk mereka harus fakta "Produk kami sepenuhnya organik". Green marketing tidak hanya ungkapan; itu strategi pemasaran yang manajer gunakan untuk membantu mereka mendapatkan lebih banyak klien dan keuntungan. Namun, hanya terjadi jika anda melakukannya secara etis. Perusahaan yang kreatif dan inovatif pasti selalu mengamati apa yang menjadi keinginan dan kebutuhan konsumen.

Salah satu produk yang menggunakan produk hijau adalah Philips. Perusahaan tersebut sudah terkenal dalam industri elektronik dan merupakan salah satu pelopor dari green marketing di Indonesia. Teknologi lampu berbasiskan LED yang mulai dipopulerkan oleh Philips LED (Light Emiting Diode) merupakan pengembangan dari teknologi semi-konduktor, semi-konduktor merupakan bahan setengah konduktor dan setengah isolator (dalam bahasa elektro/listrik), tentu saja 
teknologi semi-konduktor ini merupakan teknologi yang terus menerus mengalami pengembangan, dan salah satunya Philips LED ini sebagai produk dari pengembangan teknologi terkini itu. Berbagai jenis lampu LED telah dikeluarkan Philips, yaitu, lampu Philips LED 7W warna putih, lampu Philips LED 12.5W warna kuning, lampu Philips LED 9W warna putih.

Philips LED ini selain menerapkan teknologi terkini juga mempunyai banyak keunggulan dibanding lampu Bohlam CFL biasa, dengan berbagai macam kegunaan baik sebagai solusi hemat energi, ramah lingkungan, ramah mata, dan berbagai keunggulan lainnya tidak salah kalau sekarang lampu LED mulai berangsur menggeser penggunaan lampu Bohlam CFL biasa. Keunggulan pertama, dengan bahan semikonduktornya ia tidak memasok energi yang begitu besar dibanding dengan Bohlam biasa, untuk masalah kualitas pencahayaan pun begitu, Daya 9 Watt lampu LED ini hampir sebanding dengan daya 60 Watt lampu Bohlam CFL biasa.

Berdasarkan hasil penelitian sebelumnya (Prastiyo, 2016), maka didapatkan simpulan bahwa eco-label berpengaruh positif dan signifikan terhadap perilaku pembelian konsumen pada produk The Bodyshop di Denpasar. Artinya dengan adanya informasi akurat, penggunaan produk ramah lingkungan dan mudah dikenali semakin mendorong pembelian konsumen. Eco-brand berpengaruh positif dan signifikan terhadap perilaku pembelian konsumen pada produk The Bodyshop di Denpasar. Artinya penggunaan logo merek yang tepat bercirikan produk kosmetik yang ramah lingkungan semakin meningkatkan perilaku pembelian konsumen. Environmental advertisement berpengaruh positif dan signifikan 
terhadap perilaku pembelian konsumen pada produk The Bodyshop di Denpasar. Artinya penggunaan environmental advertisement yang tepat dan sejalan dapat membangun image untuk meningkatkan perilaku pembelian konsumen.

Begitu juga dengan (Abdul dan Rahbar, 2011) menyimpulkan hasil penelitian mereka memiliki kesamaan dengan hasil penelitian Nik Abdul Rasyid (2007), kesamaan penelitian ini dapat dilihat dari kepercayaan konsumen terhadap ecolabel. Selanjutnya, kedua studi dilakukan di Malaysia dan temuan mengungkapkan kepercayaan konsumen Malaysia dalam eco-label dan eco-brand yang mempengaruhi niat mereka untuk membeli dan juga perilaku pembelian aktual mereka. Nik Abdul Rashid (2007) berpendapat bahwa eco-label adalah sebuah konsep baru di Malaysia tidak hanya dalam hal eksistensi tetapi sebagai strategi yang digunakan oleh pemasar untuk mempengaruhi pada perilaku pembelian. Dia juga menjelaskan tidak adanya upaya kritis oleh pemasar dan produsen untuk mengembangkan kepercayaan dalam eco-label dan eco-brand kalangan Malaysia dikonsumen dan dengan demikian, apa pun kepercayaan mereka memiliki akan cenderung disengaja dan ini dihasilkan dari interaksi konsumen dengan isu yang berkaitan dengan lingkungan.

Lee (2008) menyatakan tiga tahap kemunculan pemasaran hijau. Tahap pertama dari pemasaran hijau muncul sejak tahun 1980-an, ketika gagasan pemasaran hijau baru diinisiasi dalam industry, Peattie dan Crane (2005). Pemasaran hijau pergi ke tahap kedua pada 1990-an, dalam dekade ini serangan balasan tertentu dialami oleh pemasar. Pemasar menangkap bahwa konsumen 
perhatian, sikap positif mereka terhadap lingkungan dan produk hijau tidak diterjemahkan ke dalam perilaku pembelian.

Sejak tahun 2000, pemasaran hijau telah berkembang menjadi tahap ketiga. Pada tahap ini pemasaran hijau telah melalui momentum baru lagi dengan penerapan teknologi yang lebih maju, regulasi ketat oleh pemerintah dan peningkatan kesadaran lingkungan global. Menurut Hartmann dan Iba'n ez (2006) pemasaran hijau umumnya berfokus pada efisiensi strategi persuasi kognitif, dan percaya bahwa keterlibatan tinggi konsumen mengenai isu lingkungan adalah efek dari tumbuh pengetahuan lingkungan. Definisi pemasaran hijau atau lingkungan sebagai tindakan yang dimaksudkan untuk menggantikan kebutuhan saat ini dengan dampak berbahaya minimal pada lingkungan kita.

Ginsberg dan Bloom (2004) menyatakan bahwa tidak ada alat pemasaran hijau yang akan sesuai untuk semua perusahaan. Sebaliknya, strategi harus berbeda berdasarkan pasar yang berbeda dan tingkat kepedulian konsumen terhadap lingkungan. Tiga alat pemasaran hijau dianggap dalam penelitian ini sebagai tambahan pengetahuan konsumen tentang produk yang ramah lingkungan. Saat ini, alat ini juga digunakan untuk membantu konsumen membedakan antara produk hijau dan produk konvensional. Alat-alat ini termasuk eco-brand, eco-label dan environmental advertisement.

Salah satu green marketing Tool's yang berpengaruh signifikan yaitu menggunakan eco-label pada ramah lingkungan. Produk label lingkungan semakin sering digunakan oleh pemasar untuk mempromosikan identifikasi produk hijau D'Souza et al. (2006). Sammer and Wüstenhagen (2006) mengidentifikasi eco- 
label sebagai alat penting untuk informasi dialokasikan antara penjual dan pembeli. Mereka juga menyatakan bahwa label merupakan sinyal untuk mencapai dua fungsi utama bagi konsumen: fungsi informasi yang memberitahu mereka tentang karakteristik produk seperti fungsi kualitas dan nilai produk yang memberikan nilai dalam diri mereka sendiri (misalnya pengetahuan). Selain itu, Rex dan Baumann (2007) mendefinisikan eco-label sebagai alat bagi konsumen untuk memfasilitasi pengambilan keputusan untuk memilih produk ramah lingkungan juga memungkinkan mereka untuk mengetahui bagaimana produk dibuat. Banyak studi tentang eco-label mencari cara untuk membuat mereka efektif dalam perilaku pembelian konsumen dari produk yang aman lingkungan (D'Souza et al, 2006; Sammer dan Wu“stenhagen, 2006).

Isu penting mengakui dampak eco-label pada konsumen dan pengaruh terhadap lingkungan dan apakah mereka menganggap eco-label dapat mempengaruhi dalam pengambilan keputusan mereka. Nik Abdul Rashid (2009) telah menunjukkan bahwa kesadaran eco-label berpengaruh positif antara pengetahuan tentang produk hijau dan niat konsumen untuk membeli. Namun, beberapa penelitian lain menunjukkan bahwa meskipun fungsi label diakui oleh beberapa konsumen tetapi ini tidak secara otomatis menyebabkan mereka untuk mengambil keputusan pembelian hijau (Leire dan Thidell, 2005).

Beberapa penelitian telah menyelidiki hubungan antara label lingkungan dan niat konsumen dan perilaku untuk membeli produk ramah lingkungan (D'Souza, 2004; Nik Abdul Rashid, 2009; Whitson dan Henry, 1996). Selain itu, D'Souza (2004) menjelaskan bahwa sedikit yang mengerti tentang pengaruh informasi label 
lingkungan pada niat konsumen untuk membeli produk yang ramah lingkungan. Misalnya, di pasar dengan konsumen rendahnya kesadaran tentang isu-isu lingkungan, eco-labeling sebagai alat pemasaran hijau tidak efektif. Salah satu alasan untuk ketidakefektifan ini adalah kurangnya kepercayaan konsumen dari skema eco-label. Dalam beberapa kasus ketidakpercayaan konsumen eco-label dapat diungkapkan melalui ketidaktahuan mereka dalam mengidentifikasi ecolabel dan peraturan yang mengotorisasi perusahaan untuk menempatkan label pada produk mereka. Dalam hal ini peneliti seperti Bleda dan Valente (2008) menyatakan bahwa kinerja skema eco-labeling telah menunjukkan dampak buruk dalam beberapa situasi, sedangkan, beberapa pemasar menggambarkan bahwa situasi ini akan muncul dengan pertumbuhan polusi dari memperbesar pasar di hasil pencapaian pangsa pasar yang lebih besar melalui produk-produk yang ramah lingkungan diproduksi.

Selain itu, tidak banyak yang telah dikatakan tentang pengaruh proses kognitif membaca informasi label sebagai kriteria pilihan yang digunakan konsumen untuk melakukan pembelian hijau. Menurut Nik Abdul Rashid (2009), eco-label adalah instrumen menarik menginformasikan konsumen tentang dampak lingkungan dari keputusan pembelian mereka. Untuk membantu konsumen mengidentifikasi produk-produk yang lebih disukai lingkungan dibandingkan produk sejenis lainnya, skema eco-labeling yang dimulai dalam rangka untuk mempromosikan konsumerisme lingkungan. Skema eco-label pertama telah dikembangkan sejak 1977an di Jerman (Blue Angel Eco-label). Untuk saat ini, ada sekitar 30 berbeda skema label hijau di seluruh dunia. Negara-negara Asia seperti 
Cina, Jepang, Korea, India, Thailand, Malaysia dan Singapura telah meluncurkan skema eco-labeling mereka sendiri. Penelitian ini berkaitan dengan pengakuan konsumen dari berbagai label, penggunaan eco-label dan pemahaman eco-label yang berarti dan kepercayaan dari pesan label.

The American Marketing Association mendefinisikan merek sebagai "sebuah nama, istilah, tanda, simbol, atau desain, atau kombinasi dari mereka, yang dimaksudkan untuk mengidentifikasi barang atau jasa dari satu penjual atau kelompok penjual dan untuk membedakan mereka dari orang-orang dari pesaing." Definisi ini dapat digeneralisasi untuk eco-brand juga. Eco-brand adalah nama, simbol atau desain produk yang tidak berbahaya bagi lingkungan. Memanfaatkan fitur eco-brand dapat membantu konsumen membedakan produk hijau dalam beberapa cara dari produk non-hijau lainnya. Konsumen akan berusaha untuk membeli alternatif produk ramah lingkungan untuk produk yang dihasilkan tingkat tinggi dampak lingkungan dibandingkan dengan mereka yang tingkat rendah dampak lingkungan (Chatterjee, 2009). Menurut sebuah studi sebelumnya oleh Rahbar dan Abdul Wahid (2010), konsumen Malaysia mempertimbangkan pembelian kaca berdasarkan, membersihkan rumah tangga, aerosol, pestisida dan plastik sebagai kategori produk non-hijau dengan tingkat tinggi dampak lingkungan. Oleh karena itu, dapat diprediksi bahwa konsumen akan merespon positif untuk produk dengan fitur lingkungan yang dikenal sebagai produk ecobrand. Penelitian sebelumnya di negara-negara barat mendukung ide ini bahwa konsumen di Amerika Serikat dan Jerman mengambil tindakan positif untuk produk eco-brand seperti Body Shop dan energi hijau (Wustenhagen dan Bilharz, 2006). 
Memahami pengaruh merek terhadap keputusan pembelian konsumen sangat penting bagi pemasar dan peneliti pemasaran. Pengaruh ini dikenal sebagai ekuitas merek. Brand equity, dari sudut pandang konsumen, dapat didefinisikan sebagai efek diferensial pengetahuan merek memiliki respon konsumen terhadap pemasaran merek itu. Merek hijau harus digunakan untuk menekankan posisi bahwa produk hijau melakukan sama dengan yang non-hijau. Juga, merek hijau harus digunakan untuk membantu konsumen membedakan merek hijau dari lain merek yang serupa dengan fungsi yang sama. Faktor penting yang memotivasi konsumen untuk mengubah perilaku pembelian aktual untuk membeli produk ramah lingkungan adalah manfaat merek emosional (Hartmann et al., 2005). Dengan demikian, perilaku pembelian akan beralih untuk membeli produk ramah lingkungan sebagai hasil dari pertimbangan manfaat merek hijau. Konsumen yang mengakui diri mereka sebagai konsumen yang sadar lingkungan lebih memilih untuk memilih produk hijau dalam pembelian aktual mereka untuk memenuhi kebutuhan emosional mereka.

Sejalan dengan meningkatkan gerakan hijau di seluruh dunia dan dengan meningkatnya perhatian publik terhadap masalah lingkungan, sebagian besar organisasi memilih iklan lingkungan melalui media atau koran sebagai teknik hijau untuk memperkenalkan produk mereka kepada konsumen yang bertanggung jawab terhadap lingkungan. Tujuan dari iklan hijau adalah untuk mempengaruhi perilaku pembelian konsumen dengan mendorong mereka untuk membeli produk yang tidak merusak lingkungan dan untuk mengarahkan perhatian mereka terhadap 
konsekuensi positif dari mereka, perilaku pembelian untuk diri sendiri maupun lingkungan.

Iklan lingkungan oleh perusahaan biasanya mengandung tiga unsur. Pertama, iklan dimulai dengan pernyataan dari kepedulian perusahaan terhadap lingkungan. Kedua, iklan menggambarkan cara perusahaan telah berubah prosedur untuk menunjukkan kepedulian dan dedikasi dalam memperbaiki lingkungan. Ketiga, iklan menggambarkan tindakan lingkungan spesifik di mana korporasi terlibat dan/atau hasil yang korporasi mengambil kredit.

Iklan lingkungan membantu untuk membentuk konsumen nilai-nilai dan menerjemahkan nilai-nilai ini ke dalam pembelian produk hijau. Seperti yang dinyatakan oleh Chan (2004), pesan lingkungan dalam iklan dan label produk ditemukan "kadang-kadang" mempengaruhi keputusan pembelian dari 70 persen responden. Dalam studi yang sama, lebih dari separuh responden menunjukkan bahwa mereka dibayar kurang memperhatikan pesan tersebut karena kelebihan penggunaan, dan sebagian besar responden melaporkan bahwa iklan lingkungan yang tidak kredibel. Chan (2004) menyatakan alasan utama untuk kredibilitas dirasakan rendah dalam iklan lingkungan. Alasannya, argumen jelas untuk mendukung klaim lingkungan, negara sumber yang diiklankan produk tidak menanggung gambar ramah lingkungan, produsen (pengiklan) dari yang diiklankan produk tidak menanggung gambar ramah lingkungan dan dugaan eco-friendliness dari yang diiklankan produk tidak sesuai dengan pengalaman konsumsi sebelumnya responden. 
Kotler (2008), tujuan pemasaran adalah memenuhi dan memuaskan kebutuhan serta keinginan pelanggan sasaran. Bidang ilmu perilaku konsumen mempelajari bagaimana individu, kelompok, dan organisasi memilih, membeli, memakai serta memanfaatkan barang, jasa, gagasan, atau pengalaman dalam rangka memuaskan kebutuhan dan hasrat mereka. Menurut Assauri (2009:123) perilaku konsumen merupakan tindakan seseorang atau individu yang langsung menyangkut pencapaian dan penggunaan produk termasuk proses keputusan yang mendahului dan menentukan tindakan tersebut.

Berdasarkan beberapa pendapat tersebut dapat dikatakan perilaku konsumen merupakan kegiatan-kegiatan konsumen secara langsung terlibat dalam mendapatkan dan mempergunakan barang dan atau jasa, termasuk didalamnya proses pengambilan keputusan untuk membeli dan memakai suatu produk.

Menurut (Kotler dan Armstrong, 2012:158) pada tahap permulaan, para pemasar dapat memperoleh suatu pengertian yang jelas mengenai konsumen, melalui pengalaman sehari-hari pada waktu menjual sesuatu kepada konsumen. Setelah perusahaan dan pasar semakin besar, hilanglah peluang para pembuat keputusan pemasaran untuk dapat berhubungan langsung dengan para pelanggan. Dalam tahap selanjutnya, para manajer berpaling pada penelitian konsumen, untuk mempelajari konsumen.

Rangsangan pemasaran terdiri dari empat $\mathrm{P}$, product (produk), price (harga), place (tempat), dan promotion (promosi). Rangsangan lain meliputi kekuatan dan faktor utama dalam lingkungan pembeli: ekonomi, teknologi, politik, dan budaya. Semua masukan ini memasuki kotak hitam pembeli, dimana masukan ini diubah 
menjadi sekumpulan respon pembeli yang dapat diobservasi: pilihan produk, pilihan merek, pilihan penyalur, waktu pembelian, dan jumlah pembelian.

Pemasar ingin memahami bagaimana rangsangan itu diubah menjadi respons di dalam kotak hitam konsumen, yang mempunyai dua bagian. Pertama, karakteristik pembeli mempengaruhi bagaiman pembeli menerima dan beraksi terhadap rangsangan itu. Kedua, proses keputusan pembeli itu sendiri mempengaruhi perilaku pembeli, Pertama dapat dilihat karakteristik pembeli ketika karakteristik itu mempengaruhi perilaku pembeli dan kemudian mendiskusikan proses keputusan pembeli.

Apa yang membuat suatu produk yang ramah lingkungan mempengaruhi perilaku pembelian konsumen (consumers'purchase behavior), telah menjadi suatu perdebatan serius antara environmentalis, pejabat pemerintah, perusahaan manufaktur dan konsumen. Menurut Muslim (2014) eco-label mempengaruhi kesadaran konsumen secara signifikan untuk bersedia membeli produk hijau. Hasil penelitian Melisa (2014) menunjukkan bahwa green product memberikan pengaruh yang positif dan signifikan terhadap keterlibatan konsumen yang berdampak pada keputusan pembelian konsumen. Penelitian oleh Syahbandi (2012) menemukan bahwa produk hijau berpengaruh terhadap pilihan konsumen, produk yang ramah lingkungan tersebut berhubungan secara positif dengan pilihan konsumen pada produk tersebut. Hasil penelitian Delafrooz (2014) menunjukkan bahwa ada pengaruh positif dan signifikan antara eco-label terhadap perilaku pembelian konsumen. Berdasarkan telaah kajian penelitian terdahulu, maka dapat disusun hipotesis sebagai berikut. 
$\mathrm{H}_{1}$ : Eco-label berpengaruh positif dan signifikan terhadap perilaku pembelian konsumen

Penelitian oleh Bhatnagar (2012) menunjukkan bahwa variabel eco-brand mempunyai pengaruh terhadap perilaku pembelian konsumen. Hasil penelitian Kurniawan (2014) menemukan bahwa alat pemasaran hijau eco-brand berpengaruh positif dan signifikan terhadap struktur keputusan pembelian konsumen. Hasil penelitian Delafrooz (2014) menunjukkan bahwa ada pengaruh positif dan signifikan antara variabel eco-brand terhadap perilaku pembelian konsumen. Putranto (2014) dalam penelitiannya membuktikan hipotesis tentang pengaruh ecobrand pada pembelian aktual konsumen diterima karena pengaruhnya positif dan signifikan. Berdasarkan telaah kajian penelitian terdahulu, maka dapat disusun hipotesis sebagai berikut.

$\mathrm{H}_{2}$ : Eco-brand berpengaruh positif dan signifikan terhadap perilaku pembelian konsumen

Mempromosikan suatu produk dan jasa untuk memperoleh pasar dapat dilakukan dengan iklan, public relations, promosi penjualan, direct marketing dan on-site promotions. Penjual produk hijau yang cerdas akan dapat menekankan kredibilitas produk yang ramah lingkungan dengan menggunakan sustainable marketing, juga alat dan praktek komunikasi (Haery, 2013). Melisa (2014) dalam penelitiannya menemukan bahwa promosi melalui green advertising memberikan pengaruh yang positif dan signifikan terhadap keterlibatan konsumen yang berdampak pada keputusan pembelian konsumen perusahaan Laksmi florist. Kurniawan (2014) dalam penelitiannya menemukan bahwa environmental advertisement sebagai alat pemasaran hijau berpengaruh positif dan signifikan 
terhadap struktur keputusan pembelian konsumen. Putranto (2014) dalam penelitiannya membuktikan hipotesis tentang pengaruh environmental advertisement pada pembelian aktual konsumen diterima karena pengaruhnya positif dan signifikan. Karbala (2012) menemukan bahwa periklanan hijau berkontribusi secara signifikan dalam mempengaruhi konsumen untuk membeli produk. Siswanto (2013) membuktikan bahwa environmental advertising mempengaruhi minat beli pada produk elektronik AC Inverter Panasonic pada konsumen di Surabaya. Berdasarkan telaah kajian penelitian terdahulu, maka dapat disusun hipotesis sebagai berikut.

$\mathrm{H}_{3}$ : Environmental advertisement berpengaruh positif dan signifikan terhadap perilaku pembelian konsumen.

\section{METODE PENELITIAN}

Lokasi penelitian ini adalah Kota Denpasar. Pemilihan lokasi ini berdasarkan pertimbangan bahwa Kota Denpasar merupakan daerah yang memiliki struktur masyarakat dengan tingkat heterogenitas yang tinggi dan banyaknya jumlah pendatang, merupakan pusat pemerintahan, pendidikan, perekonomian dan perdagangan. Berdasarkan hal ini maka diharapkan hasil penelitian dapat melingkupi berbagai latar belakang karakteristik konsumen.

Variabel bebas dalam penelitian ini adalah elemen-elemen alat pemasaran hijau yaitu: eco-label (X1), eco-brand (X2), dan environmental advertisement (X3). Variabel terikat dalam penelitian ini adalah perilaku pembelian konsumen (Y).

Populasi yang digunakan dalam penelitian ini adalah konsumen yang pernah membeli produk lampu Phillips LED, dengan jumlah angka populasi yang tidak dketahui dengan jelas. Penelitian ini menggunakan 14 indikator, sehingga jumlah 
sampel minimal yang harus digunakan adalah: $14 \times 8=112$ orang konsumen, karena menurut (Sugiyono, 2014) penelitian yang valid minimal memiliki 100 responden, maka dalam penelitian ini sudah bisa dikatakan valid.

Metode pengumpulan data berupa penyebaran kuesioner kepada responden yang dilakukan oleh peneliti. Kuesioner terdiri dari: 1) Pertanyaan terbuka, yang berisikan pertanyaan tentang identitas responden. 2) Pertanyaan tertutup, yaitu pertanyaan yang telah disediakan oleh peneliti dan jawaban dibatasi. Pertanyaan ini akan diukur dengan Skala Likert yaitu skala 1 sampai 5.

Analisis regresi linear berganda digunakan untuk menguji hipotesis yang ada yaitu untuk melihat variabel Green Marketing Tool's (Eco-label, Eco-brand, Environmental Advertisement) terhadap perilaku pembelian konsumen maka ditentukanlah bentuk model persamaan regresi linear berganda sebagai berikut:

$$
\hat{\mathrm{Y}}=\alpha+\beta_{1} \mathrm{X}_{1}+\beta_{2} \mathrm{X}_{2}+\beta_{3} \mathrm{X}_{3}+\mathrm{i}
$$

Keterangan:

$$
\begin{aligned}
& \hat{\mathrm{Y}} \quad=\text { Perilaku Pembelian Konsumen } \\
& \alpha \quad=\text { Konstanta } \\
& \beta_{1}, \beta_{2}, \beta_{3}, \quad=\text { Koefisien regresi } \\
& \mathrm{X}_{1} \quad=\text { Eco-label } \\
& \mathrm{X}_{2} \quad=\text { Eco-brand } \\
& \mathrm{X}_{3} \quad=\text { Environmental Advertisement } \\
& \mathrm{i}=\text { Variabel pengganggu (faktor residual) }
\end{aligned}
$$

\section{HASIL PENELITIAN DAN PEMBAHASAN}

Karakteristik Responden peneltian pada konsumen yang pernah membeli produk lampu Philips LED di Kota Denpasar dapat dilihat dari beberapa kriteria yaitu: umur, jenis kelamin, pendidikan terakhir, jenis pekerjaan, pendapatan, dan media. 
Tabel 1.

Karakteristik Responden

\begin{tabular}{|c|c|c|c|c|}
\hline No & Variabel & Klasifikasi & Jumlah (Orang) & Persentase $(\%)$ \\
\hline \multirow{4}{*}{1} & \multirow{4}{*}{ Umur } & 17-30 Tahun & 85 & 75,9 \\
\hline & & 31-40 Tahun & 3 & 2,7 \\
\hline & & 41-50 Tahun & 14 & 12,5 \\
\hline & & $>50$ Tahun & 10 & 8,9 \\
\hline \multirow{4}{*}{2} & \multirow{4}{*}{ Jenis Kelamin } & Jumlah & 112 & 100,0 \\
\hline & & Perempuan & 45 & 40,2 \\
\hline & & Laki-laki & 67 & 59,8 \\
\hline & & Jumlah & 112 & 100,0 \\
\hline \multirow{4}{*}{3} & \multirow{4}{*}{ Pendidikan } & SMA & 29 & 25,9 \\
\hline & & Diploma & 3 & 2,7 \\
\hline & & $\mathrm{S} 1$ & 75 & 67,0 \\
\hline & & S2 & 5 & 4,5 \\
\hline \multirow{7}{*}{4} & \multirow{7}{*}{ Jenis Pekerjaan } & Jumlah & 112 & 100,0 \\
\hline & & Pelajar/Mahasiswa & 73 & 65,2 \\
\hline & & PNS & 4 & 3,6 \\
\hline & & TNI/Polri & 1 & 0,9 \\
\hline & & Wiraswasta & 23 & 20,5 \\
\hline & & Lain-lain & 11 & 9,8 \\
\hline & & Jumlah & 112 & 100,0 \\
\hline \multirow{3}{*}{5} & \multirow{3}{*}{ Pendapatan } & $<$ Rp. 3.000 .000 & 87 & 77,7 \\
\hline & & Rp. 3.000 .000 - Rp. 5.000 .000 & 9 & 8,0 \\
\hline & & > Rp. 5.000 .000 & 16 & 14,3 \\
\hline \multirow{11}{*}{6} & \multirow{11}{*}{ Media } & Jumlah & 112 & 100,0 \\
\hline & & $\mathrm{TV}$ & 82 & 73,2 \\
\hline & & Brosur & 7 & 6,3 \\
\hline & & Pamflet & 3 & 2,7 \\
\hline & & Internet & 3 & 2,7 \\
\hline & & Toko Elektronik & 4 & 3,6 \\
\hline & & Koran/Majalah & 9 & 8,0 \\
\hline & & Banjar & 2 & 1,8 \\
\hline & & Swalayan & 1 & 0,9 \\
\hline & & Pertemuan & 1 & 0,9 \\
\hline & & Jumlah & 112 & 100,0 \\
\hline
\end{tabular}


Berdasarkan hasil karakteristik responden yang pernah membeli produk lampu Philips LED di Kota Denpasar dengan jumlah 112 responden yang dilihat dari beberapa klasifikasi umur, responden yang paling mendominasi berusia 17-30 tahun berjumlah 85 orang dengan persentase 75,9 persen, diurutan kedua responden yang berusia 40-50 tahun berjumlah 14 orang dengan persentase 12,5 persen, disusul oleh responden yang berusia diatas 50 tahun sebanyak 10 orang dengan persentase 8,9 persen diurutan ketiga, dan yang terakhir responden berjumlah 3 orang dengan persentase 2,7 persen adalah responden yang berusia 31-40 tahun.

Sementara itu, dilihat dari jenis kelamin responden didominasi oleh laki-laki dengan jumlah 67 orang sebesar 59,8 persen dan sisanya responden perempuan sejumlah 45 orang dengan persentase 40,2 persen. Dilihat dari tingkat pendidikannya, bahwa pendidikan S1 merupakan tingkat pendidikan yang paling banyak dalam penelitian ini dengan jumlah 75 orang dengan persentase 67,0 persen, sisanya SMA dengan jumlah 29 orang dengan persentase 25,9 persen, S2 berjumlah 5 orang dengan persentase 45 persen, dan Diploma berjumlah 3 orang dengan persentase 2,7 persen.

Hasil dari data ini menunjukan bahwa jenis pekerjaan pelajar/mahasiswa menduduki tingkat teratas dengan jumlah responden 73 orang dengan persentase sebesar 65,2 persen, diposisi kedua dengan jumlah responden 23 orang dengan persentase 20,5 persen ditempati oleh jenis pekerjaan wiraswasta, selanjutnya jenis pekerjaan lain-lain (pegawai swasta, ibu rumah tangga, tenaga honorer, pengacara, dan karyawan hotel) sebanyak 11 orang dengan persentase 9,8 persen, dan diposisi 
terakhir ditempati oleh jenis pekerjaan PNS sebanyak 4 orang dengan persentase 3,6 persen dan TNI/Polri sebanyak 1 orang dengan persentase 0,9 persen.

Variabel selanjutnya adalah variabel pendapatan dengan klasifikasi paling besar dengan jumlah kurang dari Rp. 3.000.000,- sebanyak 87 orang dengan persentase 7,7 persen, diurutan kedua dengan klasifikasi lebih dari Rp. 5.000.000,sebanyak 16 orang dengan persentase 14,3 persen, diurutan terakhir dengan pendapatan Rp. 3.000.000,- sampai dengan Rp. 5.000.000,- sebanyak 9 orang dengan persentase 8 persen.

Terakhir variabel media dimana dimaksudkan dalam penelitian ini adalah dalam media apa responden melihat iklan dari lampu Philips LED tersebut, berjumlah 82 orang dengan persentase 73,2 persen ditempati oleh media iklan TV, diurutan kedua ada koran/majalah berjumlah 9 orang dengan persentase 8,0 persen, ditempat ketiga berjumlah 7 orang dengan 6,3 persen ditempati oleh media iklan brosur. Selanjutnya ada toko elektronik yang berjumlah 4 oraang dengan persentase 3,6 persen, ditempat kelima dan keenam yaitu pamflet dan internet yang berjumlah 3 orang dengan persentase masing-masing 2,7 persen, selanjutnya ditempat ketujuh yaitu di banjar yang berjumlah 2 orang dengan persentase 1,8 persen, ditempat terakhir dengan masing-masing berjumlah 1 orang dengan persentase 0,9 ditempati oleh swalayan dan pertemuan.

Model analisis linear berganda digunakan untuk mencari koefisien regresi yang akan mengetahui ketergantungan satu variabel terikat dengan satu atau lebih variabel bebas. Hasil analisis regresi linear berganda dapat dilihat pada Tabel 2. 
Tabel 2.

Hasil Uji Regresi Linear Berganda

\begin{tabular}{llrrrrr}
\hline Model & \multicolumn{7}{c}{$\begin{array}{c}\text { Unstandardized Coefficients } \\
\text { B }\end{array}$} & $\begin{array}{c}\text { Standardized } \\
\text { Coefficients } \\
\text { Std. Error }\end{array}$ & \multicolumn{1}{c}{ T } & \multicolumn{1}{c}{ Sig. } \\
\hline 1 & (Constant) &, 475 &, 716 & &, 663 &, 509 \\
& X1 &, 541 &, 104 &, 339 & 5,213 &, 000 \\
& X2 &, 587 &, 104 &, 373 & 5,625 &, 000 \\
& X3 &, 467 &, 107 &, 290 & 4,366 &, 000 \\
\hline
\end{tabular}

Sumber: Data diolah, 2017

Berdasarkan Tabel 2. maka persamaan regresi linear berganda yang dapat dibentuk adalah sebagai berikut.

$$
\mathrm{Y}=0,475+0,541 \mathrm{X} 1+0,587 \mathrm{X} 2+0,467 \mathrm{X} 3
$$

Makna dari koefisien regresi tersebut dijelaskan bahwa Nilai koefisien regresi eco-label (X1) sebesar 0,541 memiliki arti eco-label berpengaruh positif terhadap perilaku pembelian konsumen pada produk lampu Philips LED di Kota Denpasar, bila nilai eco-label (X1) naik maka nilai dari perilaku pembelian konsumen (Y) akan mengalami peningkatan.

Nilai koefisien regresi eco-brand (X2) sebesar 0,587 memiliki arti eco-brand berpengaruh positif terhadap perilaku pembelian konsumen pada produk lampu Philips LED di Kota Denpasar, bila nilai eco-brand (X2) naik, maka nilai dari perilaku pembelian konsumen (Y) akan mengalami peningkatan.

Nilai koefisien regresi environmental advertisement (X3) sebesar 0,467 memiliki arti environmental advertisement berpengaruh positif terhadap perilaku pembelian konsumen pada produk lampu Philips LED di Kota Denpasar, bila nilai environmental advertisement (X3) naik, maka nilai dari perilaku pembelian konsumen (Y) akan mengalami peningkatan.

Pada penelitian ini, koefisien korelasi yang digunakan adalah nilai dari $\mathrm{R}$ karena nilai $\mathrm{R}$ dapat digunakan untuk mengukur seberapa kuat hubungan antara 
kedua variabel (Ghozali, 2012:97). Untuk melihat seberapa besar perilaku pembelian konsumen dipengaruhi oleh variabel eco-label, eco-brand, dan environmental advertisement dapat dilihat pada Tabel 3 berikut:

Tabel 3.

Hasil Uji Koefisien Korelasi dan Determinasi

\begin{tabular}{lrrrrr}
\hline Model & R & R Square & $\begin{array}{c}\text { Adjusted R } \\
\text { Square }\end{array}$ & \multicolumn{2}{c}{ Std. Error of the Estimate } \\
\hline 1 &, $891^{\mathrm{a}}$ &, 793 &, 787 & 1,99926 \\
& & & & &
\end{tabular}

Sumber: Data diolah, 2017

Nilai koefisien korelasi $\mathrm{R}=0,808$ dibandingkan dengan interpretasi menurut Sugiyono (2007:149) berikut.

$$
\begin{array}{ll}
0,00-0,199 & =\text { sangat rendah } \\
0,20-0,399 & =\text { rendah } \\
0,40-0,599 & =\text { sedang } \\
0,60-0,799 & =\text { kuat } \\
0,80-1,000 & =\text { sangat kuat }
\end{array}
$$

Karena nilai $\mathrm{R}=0,891$ berada di antara nilai $0,80-1,000$ maka dapat disimpulkan hubungan antara eco-label, eco-brand, dan environmental advertisement terhadap perilaku pembelian konsumen sangat kuat. Kemudian untuk melihat nilai koefisien determinasi yaitu seberapa besar persentase kontribusi eco-label, eco-brand, dan environmental advertisement mempengaruhi perilaku pembelian konsumen dapat dilihat dari nilai dari R Square sebesar 0,793 memiliki arti bahwa eco-label, eco-brand, dan environmental advertisement berpengaruh terhadap perilaku pembelian konsumen sebesar 79,3 persen, sedangkan sisanya 20,7 persen dipengaruhi oleh factor lain diluar model ini seperti, kepercayaan pelanggan dan sebagainya. 
Hasil uji F dapat dijelaskan dengan nilai signifikansi anova $<\alpha=0,05$ maka model ini dikatakan layak atau variabel bebas mampu menjelaskan variabel terikat, hasil uji $\mathrm{F}$ dapat dilihat dalam Tabel 4 berikut:

Tabel 4.

\section{Hasil Uji F}

\begin{tabular}{ccccccc}
\hline & Model & Sum of Squares & df & Mean Square & F & Sig. \\
\hline 1 & Regression & 1654,717 & 3 & 551,572 & 137,995 &, $000^{\mathrm{b}}$ \\
& Residual & 431,681 & 108 & 3,997 & & \\
& Total & 2086,398 & 111 & & & \\
\hline
\end{tabular}

Sumber: Data diolah, 2017

Berdasarkan Tabel 4 menunjukkan nilai signifikansi sebesar 0,000 yang lebih kecil dari nilai $\alpha=0,05$ maka $\mathrm{H}_{1}$ diterima, eco-label, eco-brand, dan environmental advertisement berpengaruh secara signifikan terhadap perilaku pembelian konsumen, model regresi linear berganda ini layak digunakan sebagai alat analisis untuk menguji pengaruh variabel bebas terhadap variabel terikat.

Pengujian hipotesis yang menggunakan uji t untuk menguji pengaruh masingmasing variabel bebas yaitu eco-label, eco-brand, dan environmental advertisement terhadap variabel terikat yaitu perilaku pembelian kembali. Tabel 2 menunjukkan hasil perhitungan pengujian hipotesis adalah nilai signifikansi uji t sebesar 0,000 lebih kecil daripada $\alpha=0,05$, maka $\mathrm{H}_{0}$ ditolak. Hasil ini mendukung hipotesis $\mathrm{H}_{1}$ yang menyatakan bahwa dukungan eco-label berpengaruh positif dan signifikan terhadap perilaku pembelian konsumen pada produk lampu Philips LED di Kota Denpasar. Hal ini disebabkan karena label lingkungan yang dicantumkan pada produk kemasan Philips LED sangat membantu konsumen untuk mengambil keputusan pembelian produk ramah lingkungan. Pada era globalisasi konsumen 
tidak hanya mencari produk yang monoton, tetapi harus juga memiliki nilai lebih terhadap konsumen itu sendiri khususnya ramah lingkungan.

Hasil penelitian ini mengacu pada hasil penelitian sebelumnya, Melisa (2014) menunjukkan bahwa green product memberikan pengaruh yang positif dan signifikan terhadap keterlibatan konsumen yang berdampak pada keputusan pembelian konsumen. Penelitian oleh Syahbandi (2012) menemukan bahwa produk hijau berpengaruh terhadap pilihan konsumen, produk yang ramah lingkungan tersebut berhubungan secara positif dengan pilihan konsumen pada produk tersebut. Hasil penelitian Delafrooz (2014) menunjukkan bahwa ada pengaruh positif dan signifikan antara eco-label terhadap perilaku pembelian konsumen.

Berdasarkan Tabel 2 nilai signifikansi uji t sebesar 0,000 lebih kecil daripada $\alpha=0,05$, maka $\mathrm{H}_{0}$ ditolak. Hasil ini mendukung hipotesis $\mathrm{H}_{2}$ yang menyatakan bahwa eco-brand berpengaruh positif dan signifikan terhadap perilaku pembelian konsumen pada produk lampu Philips LED di Kota Denpasar. Hal ini disebabkan karena eco-brand Philips sendiri sudah sangat dikenal oleh masyarakat Indonesia khususnya di Denpasar dan merupakan produk yang memiliki daya tarik yang kuat, maka dari itu tidak heran jika eco-brand dapat mempengaruh perilaku pembelian konsumen di Kota Denpasar.

Hasil penelitian ini mengacu pada penelitian sebelumnya oleh Bhatnagar (2012) menunjukkan bahwa variabel eco-brand mempunyai pengaruh terhadap perilaku pembelian konsumen. Hasil penelitian Kurniawan (2014) menemukan bahwa alat pemasaran hijau eco-brand berpengaruh positif dan signifikan terhadap struktur keputusan pembelian konsumen. Hasil penelitian Delafrooz (2014) 
menunjukkan bahwa ada pengaruh positif dan signifikan antara variabel eco-brand terhadap perilaku pembelian konsumen.

Berdasarkan Tabel 2 nilai signifikansi uji t sebesar 0,000 lebih kecil daripada $\alpha=0,05$, maka $\mathrm{H}_{0}$ ditolak. Hasil ini mendukung hipotesis $\mathrm{H}_{3}$ yang menyatakan bahwa environmental advertisement berpengaruh positif dan signifikan terhadap perilaku pembelian konsumen pada produk lampu Philips LED di Kota Denpasar. . Hal ini disebabkan karena Philips LED sudah tepat menggunakan media untuk memasarkan produknya, tentunya ditambah dengan perlahan melalui iklan Philips membangun image dan kepercayaan dimata konsumennya sebagai produk lampu hemat energi yang ramah lingkungan.

Berdasarkan hasil penelitian sebelumnya, penjual produk hijau yang cerdas akan dapat menekankan kredibilitas produk yang ramah lingkungan dengan menggunakan sustainable marketing, juga alat dan praktek komunikasi (Haery, 2013). Melisa (2014) dalam penelitiannya menemukan bahwa promosi melalui green advertising memberikan pengaruh yang positif dan signifikan terhadap keterlibatan konsumen yang berdampak pada keputusan pembelian konsumen perusahaan Laksmi florist. Kurniawan (2014) dalam penelitiannya menemukan bahwa environmental advertisement sebagai alat pemasaran hijau berpengaruh positif dan signifikan terhadap struktur keputusan pembelian konsumen.

\section{SIMPULAN DAN SARAN}

Berdasarkan hasil pembahasan, didapat simpulan hasil penelitian tentang pengaruh green marketing Tool's terhadap perilaku pembelian kosnumen, adalah eco-label berpengaruh positif dan signifikan terhadap perilaku pembelian 
konsumen pada produk lampu Philips LED di Kota Denpasar, artinya dengan adanya informasi akurat, penggunaan produk ramah lingkungan, dan mudah dikenali semakin mendorong pembelian konsumen.

Eco-brand berpengaruh positif dan signifikan terhadap perilaku pembelian konsumen pada produk lampu Philips LED di Kota Denpasar. Artinya penggunaan logo merek yang tepat bercirikan produk lampu yang hemat energy dan ramah lingkungan semakin meningkatkan perilaku pembelian konsumen.

Environmental Advertisement berpengaruh posititf dan signifikan terhadap perilaku pembelian konsumen pada produk lampu Philips LED di Kota Denpasar. Artinya penggunaan media iklan yang tepat dan sejalan dapat membangun image untuk meningkatkan perilaku pembelian konsumen.

Berdasarkan Standardized Coefficients Beta diperoleh hasil bahwa Ecobrand adalah alat Green Marketing Tool's yang berpengaruh dominan terhadap perilaku pembelian konsumen pada produk lampu Philips LED di Kota Denpasar. Artinya alat Green Marketing Tool's yang paling berpengaruh terhadap perilaku pembelian produk lampu Philips LED adalah Eco-brand yaitu dengan menggunakan logo merek yang mencerminkan produk lampu ramah lingkungan.

Berdasarkan simpulan, maka saran yang dapat diajukan bagi manajemen perusahaan untuk meningkatkan Eco-brand dengan memperkuat informasi merek sebagai produk yang ramah lingkungan sehingga dapat menjadi daya tarik yang kuat bagi konsumen.

Environmental advertisement ditingkatkan pelaksanaannya dengan lebih menggandeng komunitas dan organisasi non profit sebagai panduan informasi bagi 
konsumen untuk membuat keputusan pembelian. Untuk perusahaan Philips agar lebih meningkatkan dan memperelas fungsi Eco-label, Environmental Advertisement supaya konsumen mengetahui pasti fungsi Eco-label dan kegunaan Environmental Advertisement sendiri.

Bagi peneliti selanjutnya dengan topik yang sama, hendaknya memperluas obyek penelitian, tidak hanya pada lampu Philips atau The Bodyshop seperti penelitian sebelumnya namun juga produk yang lain seperti produk makananminuman, produk transportasi, sehingga dapat diketahui perbedaan pengaruh green mareting Tool's terhadap perilaku pembelian konsumen pada setiap jenis produk. Penelitian yang akan datang juga disarankan untuk menambah variabel-variabel lain yang berpengaruh terhadap perilaku pembelian konsumen seperti program promosi, atribut produk, brand equity sehingga mampu memberikan nilai indeks yang lebih tinggi serta dapat menghasilkan gambaran yang lebih luas tentang masalah penelitian yang sedang diteliti.

\section{REFERENSI}

Assauri, Sofjan. (2009). Manajemen Pemasaran Dasar, Konsep dan Strategi, Edisi Pertama. Jakarta: Raja Grafindo Persada

Abdul, Rahbar. (2011). Investigation of Green Marketing Tool's' Effect on Consumers' Purchase Behavior. Business Strategy Series. 12 (2), pp: 73-83.

Bleda, M. and Valente, M. (2008), "Graded eco-labels: a demand-oriented approach to reduce pollution', Technological Forecasting and Social Change, TFS-17065, p. 13.

Bhatnagar, Vidushi. (2012). An Environmental Protection Tool: Green Marketing and Its Effect on Consumer (Buying) Behaviour. International Journal of Emerging Research in Management and Technology, pp: 19-23.

Chan, R.Y.K. (2004), "Consumer responses to environmental advertising in China', Department of Management and Marketing, Hong Kong Polytechnic University, Kowloon, Hong Kong, Vol. 22 (4), pp. 427-37. 
Chatterjee, P. (2009), “Green brand extension strategy and online communities", Journal of Systems and Information Technology, Vol. 11 (4), pp. 367-84.

D’Souza, C. (2004), “Ecolabels programmes: a stakeholder (consumer) perspective', Corporate Communication: An International Journal, Vol. 9 (3), pp. 179-88.

D'Souza, C., Taghian, M. and Lamb, P.(2006), "An empirical study on the influence of environmental labels on consumers", Corporate Communication: An International Journal, Vol. 11 (2), pp. 162-73.

Ginsberg, J.M. and Bloom, P.N. (2004), "Choosing the right green marketing strategy”, MIT Sloan Management Review, Vol. 46 (1), pp. 79-84.

Haery, Fariddeddin Allameh. (2013). Effect of Green Marketing on Consumer Purchase Intentions with Rhaeryegard to the Company's Image as a Mediator in the Retail Setting Case study: The Customers of Naghshe-e Jahan Sugar Company. International Journal of Academic Research in Business and Social Sciences 3 (11), pp: 442-552.

Hartmann, P. and Iba'n ez, V.A. (2006), 'Green value added', Marketing Intelligence \& Planning, Vol. 24 No. 7, pp. 673-80.

Hartmann, P., Iba'n ez, V.A. and Sainz, F.J. (2005), “Green branding effects on attitude: functional versus emotional positioning strategies', Marketing Intelligence \& Planning, Vol. 23 No. 1, pp. 9-29.

Kotler, Philip and Gary Armstrong. (2012). Prinsip-prinsip Pemasaran. Edisi 13. Jilid 1. Jakarta: Erlangga.

Kotler, Philip dan Kevin Keller. (2009). Manajemen Pemasaran Jilid 1. Jakarta: Erlangga.

Kotler, Philip. (2008). Manajemen Pemasaran Jilid 1. Jakarta: PT Indeks Kelompok Gramedia.

Kurniawan, Fery Puji Nova. (2014). Pengaruh Green Marketing Terhadap Keputusan Pembelian Konsumen Mobil Daihatsu Ayla di Daihatsu Sales Operation Blimbing Malang. Perpustakaan Digital Universitas Negeri Malang.

Lee, K. (2008), “'Opportunities for green marketing: young consumers', Marketing Intelligence \& Planning, Vol. 26 (6), pp. 573-86.

Melisa. (2014). Analisis Pengaruh Green Product dan Green Advertising Terhadap Keterlibatan Konsumen dan Dampaknya pada Keputusan Pembelian Konsumen pada Perusahaan Lakmie Florist. Jurnal Fakultas Ekonomi Universitas Bina Nusantara Jakarta, hal: 1-12.

Nik Abdul Rashid, N.R. (2009), “Awareness of eco-label in Malaysia's green marketing initiative', International Journal of Business and Management, Vol. 4 (8), pp. 132-41. 
Nik Abdul Rashid, N.R. (2007), "Employee involvement in EMS/ISO 14001 and its spillover effect in consumer environmentally responsible behavior", Universiti Sains Malaysia.

Peattie, K. and Crane, A. (2005), "Green marketing: legend, myth, farce or prophesy?', Market Research: An International Journal, Vol. 8 (4), pp. 35770.

Prastiyo, Yuni. (2016), Pengaruh Green Marketing Tool's Terhadap Perilaku Pembelian Konsumen. E-Jurnal Manajemen Unud, Vol 5 (6), 2016.

Putranto, Indra. (2014). Pengaruh Alat Pemasaran Hijau pada Perilaku Pembelian Aktual Konsumen: Studi Empiris pada Lampu Hemat Energi Merek Philips. Fakultas Ekonomika dan Bisnis Universitas Gadjah Mada.

Rahbar, Elham dan Nabsiah Abdul Wahid. (2011). Investigation of Green Marketing Tool's' Effect on Consumers" Purchase Behavior. Business Strategy. Series 12 (2), pp: 73-83.

Sammer, K. and Wu“stenhagen, R. (2006), "The influence of eco-labelling on consumer behaviour - results of a discrete choice analysis for washing machines", Business Strategy and the Environment, Vol. 15 (3), pp. 185-99.

Sugiyono. (2013). Metode Penelitian Bisnis. Bandung: Alfabeta.

Syahbandi. (2012). Implementasi Green Marketing Melalui Pendekatan Marketing Mix, Demografi dan Pengetahuan Terhadap Pilihan Konsumen (Studi The Bodyshop Pontianak) Jurnal Ekonomi, Bisnis dan Kewirausahaan. 3 (1), hal: 68-86. 